\title{
До історії вивчення прісноводної малакофауни Закарпатської області
}

\section{Юрій Фурик}

Ужгородський національний університет,Ужгород, Україна

Адреса для листування: e-mail: jurij1702@ukr.net;

Отримано: 20.08.19; прийнято до друку: 20.12.19; опубліковано: 27.12.19

Резюме. Прісноводна малакофауна Закарпаття до сьогодні маловивчена, i наші дослідження спрямовані на вирішення цієї проблеми. Ця стаття представляє аналітичний огляд наявних літературних відомостей щодо вивченості прісноводної малакофауни Закарпатської області. У ній наведено перелік усіх видів прісноводних молюсків (черевоногих та двостулкових), які були виявлені або зібрані різними авторами на території дослідження впродовж XIX-XXI ст. Загалом перелік налічує 86 видів прісноводних черевоногих молюсків із 13 родин та 33 види двостулкових, які належать до 2 родин. Один вид, Viviparus rossmaessleri (Bourguignat, 1880), зазначений лише як можливий мешканець території дослідження. Решта видів, які згадуються в проаналізованій літературі, потребують подальшого уточнення як щодо видової самостійності, так і щодо реальної наявності їх у регіоні. Значна кількість назв (видів), перерахованих у цій статті, за сучасною системою (World Register of Marine Species) зводиться до синонімів загальновизнаних видів, тому така їх кількість, яка зазначена в літературі, на нашу думку, значно перебільшена. У цій статті ми не ставимо перед собою мету скоротити цей перелік, а лише, спираючись на літературні матеріали, показуємо загальну картину щодо складу малакофауни регіону. Подальша наша робота буде спрямована на систематичне вивчення прісноводної малакофауни Закарпаття. Опираючись на власні збори з території дослідження, які проведені впродовж 2016-2019 років, у подальшому додамо наукової певності в оцінці видового складу прісноводної малакофауни Закарпатського регіону.

Ключові слова: прісноводні молюски, фауна, Gastropoda, Bivalvia, Закарпатський регіон.

\section{History of exploring the freshwater fauna molluscs of the Transcarpathian region.}

\section{Yuriy Furyk}

Uzhgorod National University, Uzhgorod, Ukraine

Correspondence: e-mail: jurij1702@ukr.net; ORCID: 0000-0002-6799-3276

\begin{abstract}
Freshwater malacofauna of Transcarpathia until today remains poorly understood and our research is aimed to contribute data on solution of this problem. This article presents an analytical review of the available literature data concerning the knowledge of freshwater molluscs fauna of the Transcarpathian region. The list of all species of freshwater molluscs (gastropods and bivalves) that were observed or have been collected by different authors in the territory during the XIX-XXI centuries is presented. Altogether the list contains 86 species of freshwater gastropods from 13 families and 33 species of bivalves, which belong to 2 families. One species, Viviparus rossmaessleri (Bourguignat, 1880) is only indicated as a possible resident of the area. Status of other species that are mentioned in the analyzed literature require further clarification, as in species of independence, and about the real presence of them in the area. The presence of some of them was confirmed as a result of our revisions of the malacological collections of natural institutions of Ukraine. A significant number of names (species) are listed in this article, by a modern classification (World Register of Marine Species), reduced to synonyms, common species, so such a taxa number, which is indicated in the literature, in our opinion, is overestimated. In this article we do not aim to reduce this list, but only based on literature data, showing the
\end{abstract}


general picture of the composition of the molluscs fauna of this region. Our further work will be aimed at the systematic study of the freshwater molluscs fauna of the Transcarpathian region, based on our own sampling from this area that were carried out during the years 2016-2019. This should add more reliable evidences in assessment of the species diversity of the freshwater malacofauna of the Transcarpathian region. As a result, the whole list of all species of freshwater molluscs available on the territory will be presented, taking into account modern views on their taxonomy.

Key words: freshwater molluscs, fauna, Gastropoda, Bivalvia, Transcarpathian Ukraine.

\section{ВСТУП}

Прісноводні молюски - невід'ємний компонент практично всіх прісноводних біоценозів. Через свою високу екологічну пластичність вони здатні населяти різноманітні типи водойм - великі та малі річки, озера, ставки, струмки та ін. Перші наукові відомості щодо прісноводних молюсків Закарпаття опубліковано наприкінці 19 століття [1]. Більш детальне вивчення малакофауни регіону припадає на середину 20 століття $[2,3]$, але ці дослідження були спорадичними та нечисленними. В останні роки фахівці звернули більш пильну увагу на малакофауну регіону $[4,5]$.

Оскільки більшість досліджень молюсків у межах Закарпаття проводились фрагментарно та несистематично, навіть таксономічний склад регіональної малакофауни залишається недостатньо вивченим. Останнє добре ілюструють результати, зокрема, наших польових досліджень $[6,7,8]$.

Метою цього огляду є узагальнення наявних літературних матеріалів щодо видового складу молюсків Закарпатської області України.

\section{МАТЕРІАЛИ Й МЕТОДИ ДОСЛІДЖЕНЬ}

Матеріалом для статті слугували результати критичного аналізу наявних літературних відомостей щодо видової різноманітності прісноводної малакофауни Закарпатського регіону. При цьому до уваги брали лише ті публікації, в яких використано збори 3 водойм Закарпаття. Викладення коротких характеристик публікацій подано в хронологічному порядку. В підсумку було складено таблицю з переліком всіх згадуваних видів із зазначенням автора (чи авторів), котрих указують для зазначеної території, та року, в якому вийшла їхня праця (Табл. 1).

\section{РЕЗУЛЬТАТИ ТА ЇХ ОБГОВОРЕННЯ}

Вперше згадки про прісноводних молюсків Закарпаття ми знаходимо в роботі Йозефа Бонковського та Мар'яна Ломницького [1], де відзначена присутність на цій території зокрема таких видів як Lymnaea stagnalis та $L$. auricularia.

Цілеспрямоване вивчення прісноводних молюсків Закарпаття насамперед пов'язують 3 іменем відомого вітчизняного паразитолога В. І. Здуна, головні праці якого присвячені дослідженню личинкових форм трематод паразитів хребетних тварин i людини. Вивчаючи в деталях будову та ценотичні зв'язки трематод, він досліджував також їхніх проміжних живителів (хазяїв). Однією 3 таких груп живителів $\epsilon$ черевоногі молюски. За чималий період своїх досліджень зібрав велику колекцію молюсків різних систематичних груп, яка нині зберігається у фондах Зоологічного музею ЛНУ ім. І. Франка. На сьогодні вона налічує понад 400 проб, які містять більше 7000 зразків [9]. Значну частину цієї колекції складають прісноводні молюски 3 території Закарпаття (93 проби, понад 969 зразків), що репрезентують 16 видів черевоногих молюсків та 6 видів двостулкових. Свої напрацювання 3 малакофауни Закарпаття В. I. Здун оприлюднив 1960 року в статті [2], де наводить перелік як наземних (53 види), так i прісноводних (29 видів), черевоногих та двостулкових молюсків, яких він зареєстрував на території Закарпатської області. 3 числа звичайних для Закарпаття прісноводних молюсків він вказує Lymnaea stagnalis, L.palustris, Radix auricularia, R.peregra, Ancylus fluviatilis, Gyraulus laevis, Valvata piscinalis, Viviparus viviparus, Sphaerium corneum, Anodonta cygnea.

У 1972 році з'явилася праця Х. Г. Макогон [3], присвячена двостулковим молюскам родини Sphaeriidae та їх паразитам фауни Західних областей УРСР. Частково цими дослідженнями була охоплена й територія Закарпаття. Загалом авторка наводить 25 видів та 4 різновидності представників Sphaeriidae, які трапляються в західних областях України, частина 3 них поширена й на території Закарпаття (Musculium lacustre; Euglesa casertanum; E. henslovana та E. subtruncata).

У дев'ятому випуску серійного видання «Фауна України» [10] А. П. Стадниченко узагальнює результати своїх багаторічних 
Видовий склад прісноводних молюсків Закарпаття (за літературними даними)

\begin{tabular}{|c|c|}
\hline Назва таксону & Автор та рік публікації \\
\hline 1 & 2 \\
\hline \multicolumn{2}{|c|}{ КЛАС GASTROPODA Cuvier, 1795} \\
\hline \multicolumn{2}{|c|}{ РОДИНА NERITIDAE Rafinesque, 1815} \\
\hline - $\quad$ Theodoxus fluviatils (Linnaeus, 1758) & $\begin{array}{l}\text { Анистратенко, Анистратенко, 2001; } \\
\text { Тарасова, 2012; Фурик, } 2018 .\end{array}$ \\
\hline - $\quad$ Theodoxus danubialis (Pfeiffer, 1828) & Мельниченко та ін., 2016; Фурик, 2018. \\
\hline \multicolumn{2}{|c|}{ РОДИНА VIVIPARIDAE Gray, 1847} \\
\hline - $\quad$ Viviparus viviparus (Linnaeus, 1758) & $\begin{array}{l}\text { Здун, 1960; Поліщук, Герасевич, 1986; } \\
\text { Анистратенко, Анистратенко, 2001; } \\
\text { Шидловський та ін., 2008; Стадниченко, } \\
\text { Гирин, 2011; Мельниченко та ін., 2016; } \\
\text { Anistratenko et al. 2018; Фурик, } 2018 .\end{array}$ \\
\hline - Viviparus ater (Christophori et Jan, 1832) & $\begin{array}{l}\text { Анистратенко, Анистратенко, 2001; } \\
\text { Мельниченко та ін. 2016; Фурик, } 2018 .\end{array}$ \\
\hline - Viviparus rossmaessleri (Burguignat, 1880) & $\begin{array}{c}\text { Анистратенко, Анистратенко, } 2001 \\
\text { (можливий). }\end{array}$ \\
\hline - $\quad$ Viviparus contectus (Millet, 1813) & $\begin{array}{l}\text { Здун,1960; Поліщук, Герасевич, 1986; } \\
\text { Стадниченко, Гирин, 2011; Мельниченко } \\
\text { та ін., 2016; Anistratenko et al. 2018; Фурик, } \\
2018 .\end{array}$ \\
\hline - $\quad$ Viviparus sphaeridius (Bourguignat, 1880) & Anistratenko et al. 2018. \\
\hline \multicolumn{2}{|c|}{ РОДИНА VALVATIDAE Gray, 1840} \\
\hline - $\quad$ Valvata cristata (O.F. Müller, 1774) & Поліщук, Герасевич, 1986. \\
\hline - $\quad$ Cincina piscinalis (O.F. Müller, 1774) & $\begin{array}{c}\text { Здун, 1960; Поліщук, Герасевич, 1986; } \\
\text { Стадниченко, Гирин, 2011; Шидловський } \\
\text { та ін., 2008; Погребняк, Сєдишева, 2015; } \\
\text { Anistratenko et al. 2018; Фурик, } 2018 .\end{array}$ \\
\hline - $\quad$ Cincina ambigua (Westerlund, 1873) & Стадниченко, Гирин, 2011. \\
\hline - Atropidina pulchella (Studer, 1820) & Поліщук, Герасевич, 1986. \\
\hline - $\quad$ Atropidina klinensis (Milaschewitch, 1881) & Стадниченко, Гирин, 2011. \\
\hline \multicolumn{2}{|c|}{ РОДИНА TERRESTRIВYTHINELLIDAE Sitnikova, Starobogatov et Anistratenko, 1992} \\
\hline $\begin{array}{l}\text { - Terrestribythinella carpathica Sitnikova, } \\
\text { Starobogatov et Anistratenko, } 1992\end{array}$ & $\begin{array}{c}\text { Ситникова и др., } 1992 \\
\text { Анистратенко, Стадниченко, } 1995 .\end{array}$ \\
\hline $\begin{array}{l}\text { - Terrestribythinella baidashnikovi Sitnikova, } \\
\text { Starobogatov et Anistratenko, } 1992\end{array}$ & $\begin{array}{c}\text { Ситникова и др., } 1992 \\
\text { Анистратенко, Стадниченко, 1995; Гураль- } \\
\text { Сверлова, Гураль, 2012; Anistratenko et al., } \\
\text { 2017; Anistratenko et al., } 2018 .\end{array}$ \\
\hline $\begin{array}{l}\text { - Terrestribythinella amphibiotica Anistratenko, } \\
1995\end{array}$ & $\begin{array}{c}\text { Анистратенко, 1995; Гураль-Сверлова, } \\
\text { Гураль, } 2012 .\end{array}$ \\
\hline \multicolumn{2}{|c|}{ РОДИНА ВЕLGRANDIELLIDAE Radoman, 1983} \\
\hline - $\quad$ Paladilhiopsis carpathica (L. Soos, 1940) & $\begin{array}{c}\text { Поліщук, Герасевич, 1986; Анистратенко, } \\
\text { Стадниченко, } 1995 . \\
\text { Гураль-Сверлова, Гураль, } 2012 .\end{array}$ \\
\hline \multicolumn{2}{|c|}{ РОДИНА LYTНОGLYPНIDAE Muhlfeldt, 1821} \\
\hline - $\quad$ Lithoglyphus naticoides (Pfeiffer, 1828) & $\begin{array}{l}\text { Поліщук, Герасевич, 1986; Стадниченко, } \\
\text { Гирин, 2011; Anistratenko et al., 2017; } \\
\text { Anistratenko et al., 2018; }\end{array}$ \\
\hline - $\quad$ Lithoglyphus pyramidatus (Mollendorff, 1873) & Анистратенко, Стадниченко, 1995. \\
\hline
\end{tabular}


До історії вивчення прісноводної малакофауни Закарпатської області

\begin{tabular}{|c|c|}
\hline & Продовження таблиці \\
\hline 1 & 2 \\
\hline \multicolumn{2}{|c|}{ РОДИНА ВITHYNIIDAE Gray, 1857} \\
\hline - Bithynia tentaculata (Linnaeus, 1758) & $\begin{array}{c}\text { Здун,1960; Поліщук, Герасевич, 1986; } \\
\text { Анистратенко, Стадниченко, 1995; } \\
\text { Шидловський та ін., 2008; Anistratenko et al., } \\
\text { 2017; Anistratenko et al., 2018; Фурик, } 2018 .\end{array}$ \\
\hline - Bithynia leachii (Sheppard, 1823) & Гураль-Сверлова, Гураль. 2012; Фурик, 2018. \\
\hline - Bithynia troschelii (Paasch, 1842) & Anistratenko et al., 2018. \\
\hline \multicolumn{2}{|c|}{ РОДИНА АМNICOLIDAE Tryon, 1863} \\
\hline - Bythinella austriaca (Frauenfeld, 1856) & $\begin{array}{l}\text { Поліщук, Герасевич, 1986; Стадниченко, } \\
\text { Гирин, 2011b; Гураль-Сверлова, Гураль, } \\
\text { 2012; Макогон, } 2014 .\end{array}$ \\
\hline - Bythinella hungarica (Hazay, 1880) & $\begin{array}{c}\text { Здун,1960; Поліщук, Герасевич, 1986; } \\
\text { Стадниченко, Гирин, 2011; Гураль-Сверлова, } \\
\text { Гураль, } 2012 .\end{array}$ \\
\hline - Bythinella sp. & Anistratenko et al. 2017. \\
\hline \multicolumn{2}{|c|}{ РОДИНА РНYSIDAE Fitzinger, 1833} \\
\hline - Aplexa hypnorum (Linnaeus, 1758) & $\begin{array}{l}\text { Поліщук, Герасевич, 1986; Стадниченко, } \\
\text { 1990; Стадниченко, Гирин, 2011; Гураль- } \\
\text { Сверлова, Гураль, 2012; Фурик, } 2018 .\end{array}$ \\
\hline - Physa fontinalis (Linnaeus, 1758) & $\begin{array}{c}\text { Здун,1960; Поліщук, Герасевич, 1986; } \\
\text { Стадниченко, } 1990 \text { Стадниченко, Гирин, } \\
\text { 2011; Anistratenko et al. 2018. }\end{array}$ \\
\hline - Physa skinneri (Taylor, 1954) & $\begin{array}{c}\text { Гарлінська, 2014; Мельниченко та ін., 2016; } \\
\text { Фурик, } 2018 .\end{array}$ \\
\hline - Costatella geterostropha (Say, 1817) & Гураль-Сверлова, Гураль, 2012; Фурик, 2018. \\
\hline - Costatella acuta (Draparnaud, 1805) & $\begin{array}{c}\text { Поліщук, Герасевич, 1986; Стадниченко, } \\
\text { Гирин, 2011; Гураль-Сверлова, Гураль, 2012; } \\
\text { Погребняк, Сєдишева, 2015; Мельниченко } \\
\text { та ін., 2016; Anistratenko et al. 2018; Фурик, } \\
2018 .\end{array}$ \\
\hline - Costatella integra (Haldeman, 1841) & $\begin{array}{l}\text { Стадниченко, 1990; Стадниченко, Гирин, } \\
2011 .\end{array}$ \\
\hline \multicolumn{2}{|c|}{ РОДИНА LYMNAEIDAE Rafineskue, 1815} \\
\hline - $\quad$ Lymnaea stagnalis (Linnaeus, 1758) & $\begin{array}{l}\text { Bąkowski, 1892; Здун,1960; Полищук, } \\
\text { Герасевич, 1986; Стадниченко, 2004; } \\
\text { Шидловський, та ін., 2008; Стадниченко, } \\
\text { Гирин, 2011; Погребняк, Сєдишева, 2015; } \\
\text { Anistratenko et al. 2017; Anistratenko et al. } \\
\text { 2018; Фурик, } 2018 .\end{array}$ \\
\hline - Lymnaea fragilis (Linnaeus, 1758) & $\begin{array}{c}\text { Стадниченко, 2004; Стадниченко, Гирин, } \\
\text { 2011; Anistratenko et al. } 2018 .\end{array}$ \\
\hline - $\quad$ Lymnaea doriana (Bourguignat, 1862) & $\begin{array}{c}\text { Стадниченко, 2004; Стадниченко, Гирин, } \\
2011 .\end{array}$ \\
\hline - $\quad$ Lymnaea corvus (Gmelin, 1791) & $\begin{array}{c}\text { Шидловський, та ін., 2008; Anistratenko et al. } \\
2018 \text { (Stagnicola); Фурик, } 2018 .\end{array}$ \\
\hline - $\quad$ Lymnaea gueretiniana (Servain, 1881) & Стадниченко, 2004. \\
\hline - $\quad$ Lymnaea palustris (O. F. Müller, 1774) & $\begin{array}{c}\text { Здун,1960; Стадниченко, 2004; } \\
\text { Шидловський, та ін., 2008; Гураль-Сверлова, } \\
\text { Гураль, 2012; Фурик, } 2018 .\end{array}$ \\
\hline - Lymnaea atra atra (Schranck, 1803) & $\begin{array}{c}\text { Стадниченко, 2004; Стадниченко, Гирин, } \\
2011 \mathrm{a} .\end{array}$ \\
\hline
\end{tabular}


Науковий вісник Східноєвропейського національного університету імені Лесі Українки. Серія: Біологічні науки, 2019, 4 (388)

\begin{tabular}{|c|c|}
\hline & Продовження таблиці \\
\hline 1 & 2 \\
\hline - Lymnaea callomphala (Servain, 1881) & Стадниченко, 2004. \\
\hline - $\quad$ Lymnaea turricula (Held, 1836) & $\begin{array}{c}\text { Стадниченко, 2004; Стадниченко, Гирин, } \\
2011 .\end{array}$ \\
\hline - $\quad$ Lymnaea vulnerata (Kuster, 1867) & Погребняк, Сєдишева, 2015; Фурик, 2018. \\
\hline - $\quad$ Lymnaea truncatula (O. F. Müller, 1774) & $\begin{array}{c}\text { Здун,1960; Поліщук, Герасевич, 1986; } \\
\text { Стадниченко, 2004; Шидловський, та ін., } \\
\text { 2008; Стадниченко, Гирин, 2011; Гураль- } \\
\text { Сверлова, Гураль, 2012; Погребняк, } \\
\text { Сєдишева, 2015; Anistratenko et al., 2017; } \\
\text { Anistratenko et al., 2018; Фурик, } 2018 .\end{array}$ \\
\hline - $\quad$ Lymnaea oblonga (Puton, 1847) & $\begin{array}{l}\text { Стадниченко, Гирин, 2011; } \\
\text { Anistratenko et al., } 2018 .\end{array}$ \\
\hline - $\quad$ Ladislavella terebra (Westerlund, 1885) & Anistratenko et al., 2018 \\
\hline - $\quad$ Lymnaea peregra (O. F. Müller, 1774) & $\begin{array}{c}\text { Поліщук, Герасевич, 1986; Стадниченко, } \\
\text { 2004; Стадниченко, Гирин, 2011; Гураль- } \\
\text { Сверлова, Гураль, 2012; Погребняк, } \\
\text { Сєдишева, 2015. }\end{array}$ \\
\hline - Lymnaea bakowskiana (Clessin, 1779) & Стадниченко, 2004. \\
\hline - Lymnaea ampullacea (Rossmässler, 1835) & Стадниченко, 2004. \\
\hline - Lymnaea intermedia (Lamarck, 1822) & $\begin{array}{c}\text { Стадниченко, Гирин, 2011; Anistratenko } \\
\text { et al. } 2018 .\end{array}$ \\
\hline - $\quad$ Lymnaea ovata (Draparnaud, 1805) & $\begin{array}{l}\text { Здун,1960; Поліщук, Герасевич, 1986; } \\
\text { Стадниченко, 2004; Шидловський, та ін., } \\
\text { 2008; Погребняк, Сєдишева, 2015; Фурик, } \\
2018 .\end{array}$ \\
\hline - $\quad$ Lymnaea lagotis (Schrank, 1803) & $\begin{array}{l}\text { Здун,1960; Поліщук, Герасевич, 1986; } \\
\text { Стадниченко, 2004; Стадниченко, 2006; } \\
\text { Anistratenko et al., } 2017 .\end{array}$ \\
\hline - $\quad$ Lymnaea fontinalis (Studer, 1820) & $\begin{array}{c}\text { Стадниченко, 2004; Стадниченко, 2006; } \\
\text { Погребняк, Сєдишева, 2015; Фурик, } 2018 .\end{array}$ \\
\hline - $\quad$ Lymnaea tumida (Held, 1836) & Стадниченко, 2004;Anistratenko et al., 2018. \\
\hline - $\quad$ Lymnaea patula (Da Costa, 1778) & $\begin{array}{c}\text { Стадниченко, 2004; Стадниченко, Гирин, } \\
2011 .\end{array}$ \\
\hline - Lymnaea hartmanni (Studer, 1820) & Стадниченко, 2004. \\
\hline - Lymnaea peregra (O. F. Müller, 1774) & Здун,1960; Фурик, 2018. \\
\hline - Lymnaea ampullacea (Rossmässler, 1835) & Anistratenko et al., 2018. \\
\hline - Lymnaea intermedia (Lamarck, 1822) & Anistratenko et al., 2018. \\
\hline - $\quad$ Lymnaea balthica (Linnaeus, 1758) & Anistratenko et al., 2018. \\
\hline - $\quad$ Lymnaea glutinosa (O. F. Müller, 1774) & Стадниченко, 2004. \\
\hline - $\quad$ Lymnaea depuyi (Locard, 1893) & Стадниченко, Гирин, 2011. \\
\hline - $\quad$ Lymnaea auricularia (Linnaeus, 1758) & $\begin{array}{l}\text { Bąkowski, 1892; Здун,1960; Поліщук, } \\
\text { Герасевич, 1986; Стадниченко, 2004; } \\
\text { Стадниченко, 2006; Стадниченко, Гирин, } \\
\text { 2011; Гураль-Сверлова, Гураль, 2012; } \\
\text { Погребняк, Сєдишева 2015; Anistratenko } \\
\text { et al., 2018; Фурик, 2018. }\end{array}$ \\
\hline - Radix ampla (Hartmann, 1821) & Anistratenko et al., 2018 \\
\hline $\begin{array}{c}\text { Lymnaea psilia psilia (Bourguignat, 1862) } \\
\text { Radix cf. parapsilia Vinarski et Glöer, } 2009\end{array}$ & $\begin{array}{c}\text { Погребняк, Сєдишева, 2015; Anistratenko } \\
\text { et al., 2018; Фурик, } 2018 .\end{array}$ \\
\hline - Lymnaea ventricosa (Brongniart, 1810) & $\begin{array}{c}\text { Стадниченко, Гирин, 2011; Anistratenko } \\
\text { et al., } 2018 .\end{array}$ \\
\hline
\end{tabular}


До історії вивчення прісноводної малакофауни Закарпатської області

\begin{tabular}{|c|c|}
\hline & Продовження таблиці \\
\hline 1 & 2 \\
\hline - Lymnaea transsylvanica (Kimakowicz, 1884) & Стадниченко, Гирин, 2011а. \\
\hline - Lymnaea fulva (Küster, 1862) & Стадниченко, 2006. \\
\hline \multicolumn{2}{|c|}{ РОДИНА ВULINIDAE Herrmansen, 1846} \\
\hline - Planorbarius corneus (Linnaeus, 1758) & $\begin{array}{c}\text { Здун,1960; Поліщук, Герасевич, 1986; } \\
\text { Стадниченко, 1990; Шидловський, та ін., } \\
\text { 2008; Стадниченко, Гирин, 2011; Погребняк, } \\
\text { Сєдишева, 2015; Мельниченко та ін., 2016; } \\
\text { Anistratenko et al., 2018; Фурик, } 2018 .\end{array}$ \\
\hline - Planorbarius purpura (O. F. Muller 1774) & $\begin{array}{c}\text { Стадниченко, Гирин, 2011; Стадниченко, } \\
\text { 1990; }\end{array}$ \\
\hline $\begin{array}{c}\text { - Planorbarius stenostoma (Burguignat in } \\
\text { Servain 1881) }\end{array}$ & \\
\hline - $\quad$ Planorbarius grandis (Dunker 1856) & $\begin{array}{c}\text { Стадниченко, 1990; Стадниченко, Гирин, } \\
2011 .\end{array}$ \\
\hline - Planorbarius banaticus (Long 1856) & Стадниченко, 1990. \\
\hline \multicolumn{2}{|c|}{ РОДИНА PLANORBIDAE Rafinesque, 1815} \\
\hline - Ancylus fluviatilis (O. F. Müller, 1774) & $\begin{array}{l}\text { Здун,1960; Поліщук, Герасевич, 1986; } \\
\text { Стадниченко, 1990; Шидловський, та ін., } \\
\text { 2008; Стадниченко, Гирин, 2011; Сверлова, } \\
\text { Гураль, 2012; Погребняк, Сєдишева, 2015; } \\
\text { Anistratenko et al., 2018; Фурик, } 2018 .\end{array}$ \\
\hline - Planorbis planorbis (Linnaeus, 1758) & $\begin{array}{l}\text { Здун,1960; Поліщук, Герасевич, 1986; } \\
\text { Стадниченко, 1990; Уваєва, 2007; } \\
\text { Шидловський, та ін., 2008; Стадниченко, } \\
\text { Гирин, 2011; Мельниченко та ін., 2016; } \\
\text { Anistratenko et al., 2018; Фурик, 2018. }\end{array}$ \\
\hline - Planorbis carinatus (O. F. Müller, 1774) & Поліщук, Герасевич, 1986. \\
\hline - Anisus contortus (Linnaeus, 1758) & $\begin{array}{c}\text { Поліщук, Герасевич, 1986; Стадниченко, } \\
\text { Гирин, } 2011 .\end{array}$ \\
\hline - Anisus leucostoma (Millet, 1813) & $\begin{array}{c}\text { Поліщук, Герасевич, 1986; Стадниченко, } \\
\text { 1990; Стадниченко, Гирин, 2011; Гураль- } \\
\text { Сверлова, Гураль, 2012; Погребняк, } \\
\text { Сєдишева, 2015; Мельниченко та ін., 2016; } \\
\text { Фурик, } 2018 .\end{array}$ \\
\hline - $\quad$ Anisus septemgyratus (Rossmässler, 1835) & $\begin{array}{l}\text { Поліщук, Герасевич, 1986; Стадниченко, } \\
\text { Гирин, 2011; Мельниченко та ін., } 2016 .\end{array}$ \\
\hline - Anisus spirorbis (Linnaeus, 1758) & $\begin{array}{l}\text { Поліщук, Герасевич, 1986; Стадниченко, } \\
\text { 1990; Шидловський, та ін., 2008; } \\
\text { Стадниченко, Гирин, 2011; Мельниченко та } \\
\text { iн., 2016; Anistratenko et al., 2018; Фурик, } \\
2018 .\end{array}$ \\
\hline - Anisus vortex (Linnaeus, 1758) & $\begin{array}{c}\text { Здун,1960; Поліщук, Герасевич, 1986; } \\
\text { Стадниченко, 1990; Шидловський, та ін., } \\
\text { 2008; Стадниченко, Гирин, 2011; } \\
\text { Мельниченко та ін., 2016; Фурик, } 2018 .\end{array}$ \\
\hline - Anisus vorticulus (Troschel 1834) & Стадниченко, Гирин, 2011. \\
\hline - $\quad$ Anisus dazuri (Morch, 1868) & Стадниченко, Гирин, 2011. \\
\hline - Anisus albus (O. F. Müller, 1774) & $\begin{array}{l}\text { Здун,1960; Поліщук, Герасевич, 1986; } \\
\text { Стадниченко, 1990; Шидловський, та ін., } \\
\text { 2008; Стадниченко, Гирин, 2011; Сверлова, } \\
\text { Гураль, 2012; Мельниченко та ін., 2016; } \\
\text { Anistratenko et al., 2018; Фурик, } 2018 .\end{array}$ \\
\hline
\end{tabular}


Науковий вісник Східноєвропейського національного університету імені Лесі Українки. Серія: Біологічні науки, 2019, 4 (388)

1

\begin{tabular}{|c|c|}
\hline 1 & 2 \\
\hline - Anisus acronicus (Ferussac 1807) & $\begin{array}{c}\text { Здун,1960; Поліщук, Герасевич, 1986; } \\
\text { Стадниченко, 1990; Шидловський, та ін., } \\
\text { 2008; Стадниченко, Гирин, 2011; Гураль- } \\
\text { Сверлова, Гураль, 2012; Мельниченко та ін., } \\
\text { 2016; Фурик, } 2018 .\end{array}$ \\
\hline - Anisus laevis (Alder, 1838) & $\begin{array}{c}\text { Здун,1960; Поліщук, Герасевич, 1986; } \\
\text { Шидловський, та ін., 2008; Стадниченко, } \\
\text { Гирин, 2011; Гураль-Сверлова, Гураль, 2012; } \\
\text { Мельниченко та ін., 2016; Фурик, } 2018 .\end{array}$ \\
\hline - Hippeutis complanatus (Linnaeus, 1758) & Мельниченко та ін., 2016. \\
\hline - Armiger crista (Linnaeus, 1758) & $\begin{array}{c}\text { Поліщук, Герасевич, 1986; Стадниченко, } \\
\text { 1990; Мельниченко та ін., } 2016 .\end{array}$ \\
\hline - Segmentina nitida (O. F. Müller, 1774) & $\begin{array}{l}\text { Поліщук, Герасевич, 1986; Стадниченко, } \\
\text { 1990; Гураль-Сверлова, Гураль, 2012; } \\
\text { Мельниченко та ін., 2016; Anistratenko et al. } \\
\text { 2018; Фурик, } 2018 .\end{array}$ \\
\hline \multicolumn{2}{|c|}{ РОДИНА ACROLOXIDAE Thiele, 1931} \\
\hline - Acroloxus lacustris (Linnaeus, 1758) & Здун, 1960. \\
\hline \multicolumn{2}{|c|}{ КЛАС ВІVALVIA Linnaeus, 1758} \\
\hline \multicolumn{2}{|c|}{ РОДИНА UNIONIDAE Rafinesque, 1820} \\
\hline - Batavusiana crassa (Philipsson, 1788) & $\begin{array}{c}\text { Поліщук, Герасевич, 1986; Гураль-Сверлова, } \\
\text { Гураль, } 2012 .\end{array}$ \\
\hline $\begin{array}{l}\text { - Batavusiana musiva gontieri (Bourguignat, } \\
1881 \text { ) }\end{array}$ & $\begin{array}{c}\text { Стадниченко, 1984; Поліщук, Герасевич, } \\
\text { 1986; Стадниченко, Гирин, } 2011 .\end{array}$ \\
\hline - Batavusiana nana cornea (Küster, 1878) & Погребняк та ін. 2008; Фурик, 2018. \\
\hline - Unio tumidus (Philipsson, 1788) & $\begin{array}{c}\text { Стадниченко, 1984; Поліщук, Герасевич, } \\
\text { 1986; Погребняк та ін. 2008; Anistratenko } \\
\text { et al. 2018; Фурик, } 2018 .\end{array}$ \\
\hline - Unio pictorum (Linnaeus, 1758) & $\begin{array}{l}\text { Здун, 1960; Поліщук, Герасевич, 1986; } \\
\text { Стадниченко, Гирин, 2011; Шидловський, та } \\
\text { iн., 2008; Anistratenko et al. 2017; Anistratenko } \\
\text { et al. 2018; Фурик, 2018. }\end{array}$ \\
\hline - Unio conus borysthenicus (Cobelt, 1879) & $\begin{array}{l}\text { Погребняк та ін. 2008; Стадниченко, Гирин, } \\
\text { 2011; Фурик, } 2018 .\end{array}$ \\
\hline - Unio rostratus gentilis (Haas, 1911) & $\begin{array}{l}\text { Погребняк та ін. 2008; Стадниченко, Гирин, } \\
\text { 2011; Фурик, } 2018 .\end{array}$ \\
\hline $\begin{array}{l}\text { - Pseudanodonta complanata (Rossmässler, } \\
1835)\end{array}$ & $\begin{array}{c}\text { Здун, } 1960 \text { (Anodonta); Поліщук, Герасевич, } \\
\text { 1986; Стадниченко, Гирин, 2011; Гураль- } \\
\text { Сверлова, Гураль, 2012. }\end{array}$ \\
\hline - Anodonta cygnea (Linnaeus, 1758) & $\begin{array}{l}\text { Здун, 1960; Поліщук, Герасевич, 1986; } \\
\text { Стадниченко, Гирин, } 2011 .\end{array}$ \\
\hline $\begin{array}{l}\text { - Anodonta anatina (A. piscinalis) (Linnaeus, } \\
1758)\end{array}$ & $\begin{array}{c}\text { Здун, 1960; Поліщук, Герасевич, 1986; } \\
\text { Шидловський, та ін., 2008; Стадниченко, } \\
\text { Гирин, 2011; Фурик, } 2018 .\end{array}$ \\
\hline - Sinanodonta woodiana (Lea, 1834) & $\begin{array}{l}\text { Янович, 2013; Anistratenko et al., 2017; } \\
\text { Anistratenko et al., } 2018 .\end{array}$ \\
\hline \multicolumn{2}{|c|}{ РОДИНА SPHAERIIDAE Deshayes, 1855} \\
\hline - $\quad$ Musculium terverianum (Dupuy, 1849) & $\begin{array}{c}\text { Стадниченко, 1984; Поліщук, Герасевич, } \\
\text { 1986; }\end{array}$ \\
\hline
\end{tabular}


До історії вивчення прісноводної малакофауни Закарпатської області

\begin{tabular}{|c|c|}
\hline & Продовження таблиці \\
\hline 1 & 2 \\
\hline - Musculium creplini (Dunker, 1845) & $\begin{array}{c}\text { Макогон, 1972; Стадниченко, 1984; Поліщук, } \\
\text { Герасевич, 1986; Погребняк та ін. 2008; } \\
\text { Стадниченко, Гирин, 2011; Гураль-Сверлова, } \\
\text { Гураль, 2012; Фурик, } 2018 .\end{array}$ \\
\hline - Musculium lacustre (O. F. Müller, 1774) & $\begin{array}{l}\text { Макогон, 1972; Anistratenko et al. 2017; } \\
\text { Anistratenko et al. 2018; Фурик, } 2018 .\end{array}$ \\
\hline - Amesoda draparnaldii (Clessin, 1873) & $\begin{array}{c}\text { Стадниченко, 1984; Поліщук, Герасевич, } \\
\text { 1986; Стадниченко, Гирин, } 2011 .\end{array}$ \\
\hline - Sphaerium corneum (Linnaeus, 1758) & $\begin{array}{c}\text { Здун,1960; Стадниченко, 1984; Поліщук, } \\
\text { Герасевич, 1986; Стадниченко, Гирин, 2011; } \\
\text { Гураль-Сверлова, Гураль, 2012; Anistratenko } \\
\text { et al., 2017; Anistratenko et al., 2018; Фурик, } \\
2018 .\end{array}$ \\
\hline - $\quad$ Sphaerium nucleus (Studer, 1820) & $\begin{array}{l}\text { Anistratenko et al., 2017; Anistratenko et al., } \\
\text { 2018; }\end{array}$ \\
\hline - Sphaerium ovale (A. Ferussac, 1807) & $\begin{array}{c}\text { Гураль-Сверлова, Гураль, 2012; Anistratenko } \\
\text { et al., 2017; Фурик, } 2018 .\end{array}$ \\
\hline - $\quad$ Pisidium amnicum (O. F. Müller, 1774) & $\begin{array}{l}\text { Здун, 1960; Шидловський, та ін., 2008; } \\
\text { Стадниченко, Гирин, 2011; Фурик, } 2018 .\end{array}$ \\
\hline - Euglesa milium (Held, 1836) & Стадниченко, 1984; Макогон, 2014. \\
\hline - Euglesa obtusalis (Lamarck, 1818) & $\begin{array}{c}\text { Поліщук, Герасевич, 1986; Стадниченко, } \\
\text { Гирин, 2011; Гураль-Сверлова, Гураль, 2012; } \\
\text { Макагон, 2014; Фурик, } 2018 .\end{array}$ \\
\hline - Euglesa scholtzi (Clessin, 1876) & $\begin{array}{c}\text { Стадниченко, 1984; Поліщук, Герасевич, } \\
\text { 1986; }\end{array}$ \\
\hline - Euglesa personata (Malm, 1885) & $\begin{array}{c}\text { Здун,1960 (Pisidium); Поліщук, Герасевич, } \\
\text { 1986; Погребняк та ін. 2008; Макогон, 2014; } \\
\text { Фурик, } 2018 .\end{array}$ \\
\hline - Euglesa nitida (Jenyns, 1832) & $\begin{array}{c}\text { Стадниченко, 1984; Поліщук, Герасевич, } \\
\text { 1986; Шидловський, та ін., 2008; Фурик, } \\
2018 .\end{array}$ \\
\hline $\begin{array}{c}\text { - Euglesa khurdunensis Pirogov et Starobogatov } \\
\text { in Stadnichenko, } 1984\end{array}$ & $\begin{array}{c}\text { Стадниченко, 1984; Поліщук, Герасевич, } \\
1986 .\end{array}$ \\
\hline - Euglesa subtruncata (Malm, 1855) & $\begin{array}{c}\text { Макогон, 1972; Поліщук, Герасевич, } 1986 \\
\text { (Pisidium); Погребняк та ін. 2008; Сверлова- } \\
\text { Гураль, Гураль, 2012; Фурик, } 2018 .\end{array}$ \\
\hline - Euglesa casertana (Poli, 1791) & $\begin{array}{c}\text { Макогон, 1972, 2014; Поліщук, Герасевич, } \\
1986 \text { (Pisidium); Гураль-Сверлова, Гураль, } \\
\text { 2012; Фурик, } 2018 .\end{array}$ \\
\hline - Euglesa henslowana (Sheppard 1823) & Макогон, 1972 \\
\hline $\begin{array}{c}\text { - Euglesa fossarina (Clessin in Westerlund, } \\
1873)\end{array}$ & $\begin{array}{c}\text { Поліщук, Герасевич, 1986; Стадниченко, } \\
\text { Гирин, 2011. }\end{array}$ \\
\hline - Euglesa obliquata (Clessin, 1874) & Погребняк та ін. 2008; Фурик, 2018. \\
\hline - Euglesa tetragona (Normand, 1854) & Стадниченко, Гирин, 2011b. \\
\hline - Neopisidium conventus (Clessin, 1877) & $\begin{array}{c}\text { Макогон, 1975, 2014; Стадниченко, 1984; } \\
\text { Поліщук, Герасевич, } 1986\end{array}$ \\
\hline - Neopisidium urinator (Clessin, 1876) & $\begin{array}{c}\text { Стадниченко, 1984; Поліщук, Герасевич, } \\
1986 .\end{array}$ \\
\hline
\end{tabular}


Науковий вісник Східноєвропейського національного університету імені Лесі Українки. Серія: Біологічні науки, 2019, 4 (388)

досліджень i тогочасних літературних відомостей про видовий склад фауни двостулкових молюсків родин перлівницевих та кулькових у межах України. Відомості щодо поширення видів, які там згадуються, частково охоплюють і територію Закарпаття. Зокрема, це такі види, як Batavusiana nana carnea; B. musiva gontieri; Unio pictorum; Anodonta cygnea; M. creplini; Amesoda draparnaldii; Spharium corneum; E. fossarina; Neopisidium conventus та деякі інші.

У 1986 році вийшла праця [11], в якій висвітлено склад та особливості розвитку гідрофауни пониззя Дунаю. Список знайдених видів гідрофауни, доповнений літературними даними, включає близько 3000 видів гідробіонтів. Серед них $\epsilon$ чимало видів прісноводних молюсків 3 басейну річки Тиса (52 види). Хоч у цій роботі не подані відомості про конкретні місця перебування згадуваних видів, але для кожного 3 них зазначено, на якій ділянці басейну Тиси він був виявлений (гірська або передгірна частини річки).

У 1990 році виходить четвертий випуск серії «Фауна України» [12], присвячений трьом родинам ряду Lymnaeiformes, a саме: Physidae, Bulinidae та Planorbidae, які досить поширені у водоймах України, зокрема й на Закарпатті. Для Закарпаття в цій роботі А. П. Стадниченко наводить такі види: Costatella integra, Planorbarius corneus, P. purpura, P.grandis, P.banaticus, Ancylus fluviatilis, Planorbis planorbis, Anisus vortex, A. albus, A.acronicus, A. laevis, Armiger crista. Окрім них, авторка наводить деякі інші види, які відзначені як такі, що поширені у всіх природно-географічних зонах України, але без конкретної прив'язки до Закарпаття.

У черговому випуску «Фауни України» [13] продовжується систематичний опис черевоногих молюсків фауни України, а саме представників двох рядів (Littoriniformes та Rissoiformes) підкласу Pectinibranchia. Серед видів, описаних у цій монографії, для Закарпаття вказують ще й такі: Terrestribythinella carpathica, T. baidashnikovi, Lithoglyphus naticoides, Bythinella austriaca, B. hungarica. Трохи згодом був описаний [14] ще один новий вид черевоногих молюсків роду Terrestribythinella 3 території Закарпатської області, а саме T. amphibiotica.

У 2001 році світ побачив останній за часом випуск серії «Фауна України», присвячений прісноводним молюскам [15]. У випуску описано нижчих представників типу Mollusca, які належать до двох класів (Polyplacophora та
Gastropoda). Представників Polyplacophora на Закарпатті немає, між тим кілька видів нижчих Gastropoda тут представлено: Theodoxus fluviatilis, Th.danasteri; Viviparus viviparus, $V$. ater та деякі інші. Також у роботі йдеться про можливість знахідки на території Закарпаття такого виду як V. rossmaessleri.

У 2006 році виходить стаття [16], у якій А. П. Стадниченко розглядає видовий склад, поширення та екологію молюсків Східних Карпат - Горган (системи гірських хребтів, розташованих у межах Івано-Франківської та Закарпатської областей). Згідно 3 відомостями цієї публікації, фауністичний склад досліджуваного регіону охоплює 104 види прісноводних черевоногих та двостулкових молюсків. Деякі 3 перерахованих авторкою видів мешкають у водоймах Закарпаття (Lymnaea fulva, L.fontinalis, L. lagotis, L. auricularia). Інші види, згадувані в цій статті, конкретної прив'язки до Закарпаття не мають.

У 2007 році було підтверджено присутність на території Закарпаття такого виду як Planorbis planorbis [17], який був засвідчений тут і раніше [2].

У 2008 році видано каталог малакологічної колекції Зоологічного музею ННПМ НАН України [18], в якому наводиться перелік усіх видів двостулкових молюсків, що зберігаються у фондах цього музею. Частина 3 цих матеріалів у різні роки була зібрана i на території Закарпаття. Перелік Закарпатських видів двостулкових 3 цього каталогу наведений в окремій статті, присвяченій малакологічним колекціям деяких природничих установ України [8]. У 2009 році Н. В. Гураль-Сверлова та Р. І. Гураль описують власні знахідки молюсків роду Terrestribythinella на території Карпатського біосферного заповідника. На думку авторів, подальша таксономічна ревізія цього роду $\epsilon$ необхідною для встановлення самостійності віднесених до нього видів [19].

У 2011 році виходять два коротких, але дуже змістовних повідомлення, які присвячені виключно молюскам Закарпаття [4,5]. У цих публікаціях наведено перелік усіх груп водних молюсків Закарпатської області. А. П. Стадниченко та В. К. Гирин зазначають, що в результаті їхніх досліджень список малакофауни регіону поповнився 27 видами. Зокрема, нові види вперше наведені для родин: Lymnaeidae (Lymnaea fragilis, L.doriana, L patula, L. intermedia, L.atra, L. dupyi, L. ventricosa, L.turricula, L. transsylvanica, L. oblonga), Physidae (Aplexa hypnorum) Valvatidae (Valvata klinensis та V.ambigua), 
До історії вивчення прісноводної малакофауни Закарпатської області

Unionidae (Batavisiana musiva gontieri, U. conus borysthenicus та $U$. rostratus gentilis), Euglesinae (Euglesa tetragona, E. obtusalis та E. fossarina). Назви видів наведено за А. П. Стадниченко та В. К. Гирин.

У 2012 році Н. Гураль-Сверлова та Р. Гураль у статті «Рідкісні та маловідомі молюски (Gastropoda et Bivalvia) Українських Карпат» обгрунтовують необхідність занесення представників родини Terrestribythinellidae, які поширені на території Закарпатської області (табл. 1), до регіональних або навіть державних червоних списків. Окрім них, автори вважають рідкісними такі види, як Paladilhiopsis carpathica, Bythinella austriaca, B. hungarica, Gyraulus acronicus, G. laevis, Unio crassus, Pseudanodonta complanata та Sphaerium ovale. На думку цих авторів, усі названі види трапляються на території Закарпаття [20].

Цього ж року виходить 3 друку каталог наукової колекції Державного природознавчого музею [21], в якому наведено перелік усіх видів молюсків, що там зберігаються. Частина цієї колекції була зібрана й на території Закарпатської області [8]. В публікації Л. М. Янович та М. М. Пампури [22] підтверджено наявність у водоймах Закарпаття Unio pictorum.

Ю. В Тарасова [23] під час власних досліджень відзначала поширення на території Закарпаття такого виду як Theodoxus fluviatilis.

Л. М. Янович [24] вказує на знахідку на території Закарпаття (р. Латориця) такого чужорідного виду як Sinanodonta woodiana. Ми також підтвердили наявність цього виду на згаданій території $[6,7]$.

У 2014 році вийшла стаття Х. Г. Макогон про деяких представників двостулкових молюсків родини Sphaeriidae, що трапляються в озері Синевир та прилеглих до нього водоймах [25]. Особливий науковий інтерес у цій статті викликає виявлення в оз. Синевир холодноводної горошинки (Neopisidium conventus), яка зазвичай мешкає у високогірних озерах Альп. Фактичне знаходження $N$. conventus в озері Синевир також було підтверджено в попередній публікації авторки [10] та в монографії А. П. Стадниченко [11]. Окрім цього озера, представників зазначеного виду більше ніхто й ніде в Україні не знаходив. Поряд із N. conventus наведені такі види: Euglesa personata, E. casertana, E. milium, E. obtusalis та представник черевоногих молюсків - Bythinella austriaca [25].

Цього ж року виходить стаття [26], де розглядають морфологічні та екологічні особливості молюсків підродини Physinae фауни України. Із 3 видів, що тут описані, один (Physa skinneri) зазначений як такий, що поширений і на Закарпатті.

У 2015 році виходить наступний каталог малакологічної колекції Зоологічного музею ННПМ НАН України [27], який присвячено черевоногим молюскам. Частина матеріалу цієї колекції була зібрана на території Закарпаття [8].

У 2016 році Р. Мельниченко, разом із колегами, публікують статтю, в якій наводять перелік усіх видів черевоногих молюсків, що зберігаються в малакологічній колекції Житомирського державного університету ім. Івана Франка [28]. Серед них є й декілька представників малакофауни Закарпатської області (басейну р. Тиси): Theodoxus danubialis, Viviparus contectus, V. viviparus, V.ater, Planorbarius corneus, Planorbis planorbis, Physa skinneri та деякі інші.

У 2017 році виходить стаття [6], в якій описано знахідки декількох нових та маловідомих видів прісноводних молюсків Закарпаття. Тут наведено дані щодо поширення в регіоні Terrestribythinella baidashnikovi, Bythinella sp., Sphaerium nucleus, Musculium lacustre та Sinanodonta woodiana. Також у цій статті повідомлено про знахідки T. baidashnikovi i поза межами Закарпаття. До цього часу цей вид вважався регіональним ендеміком.

У 2018 році видано ілюстрований фауністичний огляд усіх відомих видів родини Lymnaeidae на території Закарпатської області [7]. Деякі види відзначено в регіональній фауні вперше: Stagnicola corvus, Radix parapsilia, $R$. balthica, $R$. ampla та $R$. tumida. Також тут наведено дані про рідкісні для Закарпаття види Ladislavella terebra та Lymnaea fragilis.

Цього ж року виходить ще одна публікація [29], в якій описано унікальний випадок використання личинками волохокрильця Crunoecia irrorata Curtis, 1834 в якості будівельного матеріалу для своїх хатинок живих особин рідкісного ендемічного молюска роду Terrestribythinella. Матеріал, на основі якого написано цю статтю, був зібраний 2017 року на території Закарпатської області (КузійТрибушанський заповідний масив Карпатського біосферного заповідника).

\section{ВИСНОВКИ}

Як видно 3 проаналізованої літератури, сумарний склад прісноводних черевоногих та двостулкових молюсків, зареєстрованих у Закарпатті, включає 119 видів (табл. 1). За 
сучасними таксономічними даними (World Register of Marine Species), видовий статус деяких видів, зазначених у цьому переліку, потребує уточнень, адже багато 3 них не визнані як окремі, а їх зводять до синонімів основних (загальноприйнятних) видів, що, безумовно, призведе до скорочення загального списку. Також потребує підтвердження існування на території дослідження Theodoxus fluviatilis, Lithoglyphus pyramidatus, Paladilhiopsis carpathica, Planorbis carinatus, Euglesa henslowana та деяких інших, які неодноразово були відзначені. А отже, тестування видової самостійності кожного згадуваного виду є пріоритетним завданням для складання сучасного надійного переліку (чеклиста) прісноводних молюсків, поширених на території Закарпаття.

\section{ПОДЯКА}

Автор статті щиро вдячний своєму науковому керівнику, професору, завідувачу Відділом фауни та систематики безхребетних Інституту зоології імені I. I. Шмальгаузена В. В. Аністратенку за корисні поради під час роботи $з$ літературою та редагування рукопису статті.

\section{ЛІТЕРАТУРА}

1. Bąkowski, J.; Lomnicki, M. Miêczaki (Mollusca). Wydawnictwo Muzeum im. Dzieduszyckich: Lwów, 1891, 264 s.

2. Здун, В. І. До фауни молюсків Закарпаття. Наукові Записки Львівського науковоприродознавчого музею АН УРСР; 1960, 8. с 83-95.

3. Макогон, Х. Г. Двустворчатые моллюски семейства Sphariidae Bourg., и их паразить фаунь западньх областей УССР. Автореферат диссертации на соискание учёной степени кандидата биологических наук. Львов, 1972, 21 с.

4. Стадниченко, А. П.; Гирин, В. К. К фауне и экологии пресноводных моллюсков Закарпатья (семейства Lymnaeidae, Bulinidae, Physidae). Сообщение 1. В Materialy VII Miedzynarodowej konferencji "Wyksztalcenie i nauka bez granic" 07-15 grudnia 2011 roku. Przemyśl, 2011, 25, pp 19-21.

5. Стадниченко, А .П.; Гирин, В. К. К фауне и экологии пресноводных моллюсков Закарпатья (семейства Planorbidae, Valvatidae, Viviparidae, Hydrobiidae, Bithyniidae, Lithoglyphidae, Unionidae, Pisidiidae). Сообщение 2. В Materialy VII Miedzynarodowej konferencji "Wyksztalcenie $i$ nauka bez granic" 07-15 grudnia 2011 roku. Przemyśl, 2011, 25, pp 17-19.

6. Anistratenko, V. V.; Furyk, Yu. I.; Degtyarenko, E. V.; Anistratenko, O. Yu. New and little-known freshwater Mollusks of Ukrainian
Transcarpathian. Ecologica Montenegrina; 2017, 13, pp 70-79.

7. Anistratenko, V. V.; Vinarski, M. V.; Furyk, Yu. I.; Degtyarenko, E. V.; Anistratenko, O. Yu. New data on pond snails (Mollusca: Gastropoda: Lymnaeidae) inhabiting the Ukrainian Transcarpathian: diversity, distribution and ecology. Ecologica Montenegrina; 2018, 18, pp 1-14.

8. Фурик, Ю. І. Прісноводні молюски Закарпаття (басейн річки Тиса) у малакологічних колекціях України. Geo\&Bio; 2018, 16, с 115-122.

9. Каталог колекції прісноводних молюсків проф. В. І. Здуна у фондах Зоологічного музею ЛНУ імені Івана Франка. Укладачі: Шидловський, І. В.; Гураль, Р. І.; Романова, Х. Й. Видавничий центр ЛНУ ім. І. Франка: Львів, 2008, 58 с.

10. Стадниченко, А. П. Перлівницеві. Кулькові. (Unionidae, Cycladidae). Фауна України в 40 томах. Молюски. Наукова думка: Київ, 29(9), 1984, 373 с.

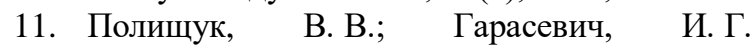
Биогеографические аспекты изучения водойомов бассейна Дуная в пределах СССР. Наукова думка: Киев, 1986, 212 с.

12. Стадниченко, А. П. Прудовикообразные (пузырчиковые, витушковые, катушковые). Фауна Украины в 40 томах. Моллюски. Наукова думка: Киев, 1990, 29(4), 292 с.

13. Анистратенко, В. В.; Стадниченко А. П. Литторинообразные. Риссоиобразные (Littoriniformes. Rissoiformes). Фауна Украины в 40 томах. Моллюски. Наукова думка: Киев, 1995 [1994], 29 (1(2)), 175 c.

14. Анистратенко, В.В. Новый вид рода Terrestribythinella (Mollusca Gastropoda Pectinibranchia) из Закарпатья. Вестник зоологии; 1995, 29(4), c 66-68.

15. Анистратенко, В. В.; Анистратенко, О. Ю. Класс Панцирные или Хитоны, класс Брюхоногие Cyclobranchia, Scutibranchia и Pectinibranchia (часть). Фауна Украинь в 40 томах. Моллюски. Велес: Киев, 2001, 29 (1(1)), 240 с.

16. Стадниченко, А. П. Фауна, поширення та екологія прісноводних молюсків Східних Карпат. Вісник Житомирського державного університету імені Івана Франка; 2006, 28, с 243-245.

17. Уваєва, О.І. Молюски роду Planorbis (Gastropoda, Planorbinae) фауни України: діагностика, особливості поширення та екологія. Вестник зоологии; 2007, 41(1), с 71-79.

18. Погребняк, С. Г.; Сєдишева, Е. М.; Корнюшин, О.В. Каталог колекцій Зоологічного музею ННПМ НАН України. Двостулкові молюски (Mollusca: Bivalvia). Видавництво Зоологічного музею ННПМ НАН України: Київ, 2008, 17 c.

19. Гураль-Сверлова, Н. В.; Гураль, Р. И. Интересные находки брюхоногих моллюсков (Gastropoda, Aciculidae, Terrestribythinellidae) на территории Украинских Карпат. Зоологический журнал; 2009, 88 (7), с 794-799.

20. Гураль-Сверлова, Н. В., Гураль, Р.І. Рідкісні та маловідомі молюски (Gastropoda et Bivalvia) 
До історії вивчення прісноводної малакофауни Закарпатської області

Українських Карпат. Наукові записки Державного природознавчого музею; 2012, 28, с. 131-142.

21. Гураль-Сверлова, Н.В.; Гураль, Р. І. Наукові колекиії Державного природознавчого музею. Малакологічний фонд; 2012, 4, 253 с.

22. Янович, Л. М.; Пампура, М. М. Сучасне поширення та популяційні характеристики Перлівниці звичайної Unio pictorum Linnaeus, 1758 (Mollusca: Bivalvia: Unionidae) в основних річкових басейнах України. Наукові записки тернопільського національного педагогічного університету імені Володимира Гнатюка. Серія: Біологія. Спеціальний випуск: «МОЛЮСКИ: РЕЗУЛЬТАТИ, ПРОБЛЕМИ I ПЕРСПЕКТИВИ ДОСЛІДЖЕНЬ»; 2012, № 2 (51), c 319-323.

23. Тарасова, Ю. В. Поширення та екологічна характеристика молюсків роду Theodoxus (Gastropoda, Pectinibranchia, Neritidae) України. Наукові записки Тернопільського національного педагогічного університету імені Володимира Гнатюка. Серія: Біологія. Спеціальний випуск: «МОЛЮСКИ: РЕЗУЛЬТАТИ, ПРОБЛЕМИ I ПЕРСПЕКТИВИ ДОСЛІДЖЕНЬ»; 2012, № 2 (51), c 276-279.

24. Янович, Л. М Перлівницеві Unioidae Rafinesque, 1820 (Bivalvia) в сучасних екологічних умовах Украйни (стан популячій, особливості статевої структури і розмноження, біоценотичні зв'язки та фауна). Автореферат дисертації доктора біологічних наук - 03.00.08 - зоологія НАН
України, Інститут зоології ім. I. І. Шмальгаузена. Київ, 2013, 48 с.

25. Макогон, Х. Г. До вивчення малакофауни Синевирського озера та його побережжя. Науковий вісник Львівського начіонального університету ветеринарної медицини та біотехнологій імені С. 3. Гжицького; 2014, 16, № 3(3), с 335-341.

26. Гарлінська, А.М. Морфологічні та екологічні особливості молюсків підродини Physinae (Mollusca: Gastropoda: Pulmonata) України. Науковий вісник Східновропейського національного університету імені Лесі Украӥнки. Біологічні науки; 2014, № 13, с 73-77.

27. Погребняк, С. Г.; Сєдишева, Е. М. Черевоногі молюски (Mollusca, Gastropoda). Колекиіi Зоологічного музею Національного науковоприродничого музею Наиіональної академії наук України. Видавництво Зоологічного музею ННПМ НАН України: Київ, 2015, 388 с.

28. Мельниченко, Р. К.; Андрійчук, Т. В.; Гарбар, Д. А.; Гарлінська, А. М.; Довбня, А. В.; Тарасова, Ю. В.; Уваєва, О. І. Черевоногі молюски малакологічної колекції ЖДУ імені Івана Франка. Науковий вісник Ужгородського національного університету. Серія Біологія; 2016, 40, с 78-82.

29. Martynov A. V.; Anistratenko, V. V.; Furyk, Yu. I. Endemic spring snails Terrestribythinella (Mollusca) as unusual material for larval case of Crunoecia irrorata (Trichoptera: Lepidostomatidae) in Transcarpathian Ukraine. Ecologica Montenegrina; 2018, 18, pp 120-125. 